\title{
Anatomic transobturator tape (TOT) technique: clinical anatomic landmarks of obturator foramen on female cadavers
}

\author{
Emre Huri ${ }^{1}$, Mehmet Ezer ${ }^{1}$, Batuhan Aydoğan ${ }^{1}$, İlkan Tatar ${ }^{2}$, Mustafa F. Sargon ${ }^{2}$ \\ ${ }^{1}$ Department of Urology, Faculty of Medicine, Hacettepe University, Ankara, Turkey \\ ${ }^{2}$ Department of Anatomy, Faculty of Medicine, Hacettepe University, Ankara, Turkey
}

\begin{abstract}
In women, stress urinary incontinence is the most common subtype of urinary incontinence. Trans-obturator slings can be used for minimally invasive treatment of stress urinary incontinence. The aim of this procedure is to place the mesh through the obturator foramen and underneath the mid part of the urethra with minimal damage to surrounding tissues. There are remarkable variations in the bony architecture of the female pelvis, and this variability may have an important effect on sling operations. Understanding the surgical anatomy of the obturator foramen, pelvic floor and perineum is necessary to make a successful implantation of transobturator tape and minimize morbidity. Cadaveric dissections are helpful to demonstrate anatomic landmarks.
\end{abstract}

Keywords: cadaveric dissection; obturator foramen; stress urinary incontinence (SUI); trans-obturator tape (TOT)

Anatomy 2015;9(1):38-41 C2015 Turkish Society of Anatomy and Clinical Anatomy (TSACA)

\section{Introduction}

Stress urinary incontinence (SUI) is the involuntary leakage of urine when intrabdominal pressure rises. In women, SUI is the most common subtype of urinary incontinence (UI) ${ }^{[1]}$ It leads to high costs to the budget of health and causes many psychosocial problems. Retropubic slings and trans-obturator slings can be used for minimally invasive treatment of SUI. Trans-obturator technique is a more beneficial and a less invasive procedure in treatment of SUI when compared with other techiniques. ${ }^{[2]}$ In this technique, a synthetic mesh tape, which is passing bilaterally through the obturator foramen, is placed underneath the mid part of the urethra.

Pelvic fresh-frozen cadaveric sample is the most useful tool for understanding the obturator foramen anatomy and peri-obturator region. Obturator region can be dissected finely to isolate each anatomic landmark, which is important to achieve excellent anatomic TOT procedure. The obturator foramen is formed by the ischium and the pubic bones. It is encircled superiorly by the grooved obturator surface of the superior pubic ramus, medially by the body and inferior ramus of the pubis, laterally by the anterior border of the body of the ischium, and below by the ramus of the ischium. ${ }^{[3]}$ Most of the obturator foramina are closed by the obturator membrane, which is a thin aponeurosis. This membrane is attached to foramen's edges except above. Obturator canal is an anatomic communication between the pelvis and the thigh, where the obturator nerve and vessels pass out of the pelvis (Figure 1). ${ }^{[3]}$

\section{Stepwise Application of Transobturator Tape Procedure Guided to Obturator Foramen}

When performing the procedure, the aim is to place the mesh through the obturator foramen and underneath the mid part of the urethra (mid-urethra) with minimal damage to surrounding tissues. Trans-obturator tape (TOT) approach varies with insertion method. Different techniques using similar insertion methods can be accepted 
as similar techniques. Regardless of the direction of passage (from outside to inside or from inside to outside), the needle will cross the skin, subcutaneous fat, the gracilis, adductor muscles, and the obturator externus muscle and fascia, the obturator membrane, the obturator internus muscle, and the periurethral endopelvic fascia (Figure 2). ${ }^{[4]}$ TOT techniques can be classified under two different titles as outside-in and inside-out without a definitive difference in terms of safety and efficacy. ${ }^{[5,6]}$

\section{Transobturator outside}

Starting with the dorsal lithotomy position, legs are taken up to 120 degrees of hyperflexion. Patient should be draped to expose the vagina, following the appropriate regional cleaning. A foley catheter is inserted to the urethra. Starting with $1-1.5 \mathrm{~cm}$ below the urethral meatus, a $1.5-2 \mathrm{~cm}$ vertical incision is made. Following the dissection of anterior vaginal mucosa, pubocervical fascia should be dissected sharply (Figure 3). Dissection is continued laterally to the ischiopubic ramus. Starting downwards from the tendinous insertion of the adductor longus muscle at the level of clitoris, a $1 \mathrm{~cm}$ incision is made close to the bone. The needle is placed in to the incision and passed as possible as medially through the obturator membrane. It has to be considered that the needle is passed very close to the bone in order not to damage the obturator vessel-nerve bundle. In order to avoid postoperative pain, the needle should not pass through the adductor longus tendon. With the guidance of the opposite hand's index finger in the vaginal incision the tip of the needle has to be palpated afterwards passing with a 45-degree angle rotation. The next manoeuvre is passing the tip of the needle beside the urethra through the vaginal incision with prevention of urethral damage. This procedure should be applied to the opposite side. ${ }^{[4,5,7]}$

\section{Transobturator inside-out}

Patient preparation and vaginal incisions are the same for both techniques. The tip of the needle is placed in to the vaginal incision with a direction to the inferior pubic ramus. The obturator membrane is passed as possible as medially up to the obturator incision which is similar to the "outside-in" technique. The same application is made towards to the opposite direction. ${ }^{[-9]}$

Sling should be connected to the needle. If inside-out technique is performed, the sling mesh has to be preconnected. It should be passed out through the incisions. An instrument like a surgical clamp has to be placed between the catheterized urethral wall and the sling mesh in order to avoid tension. The sling material

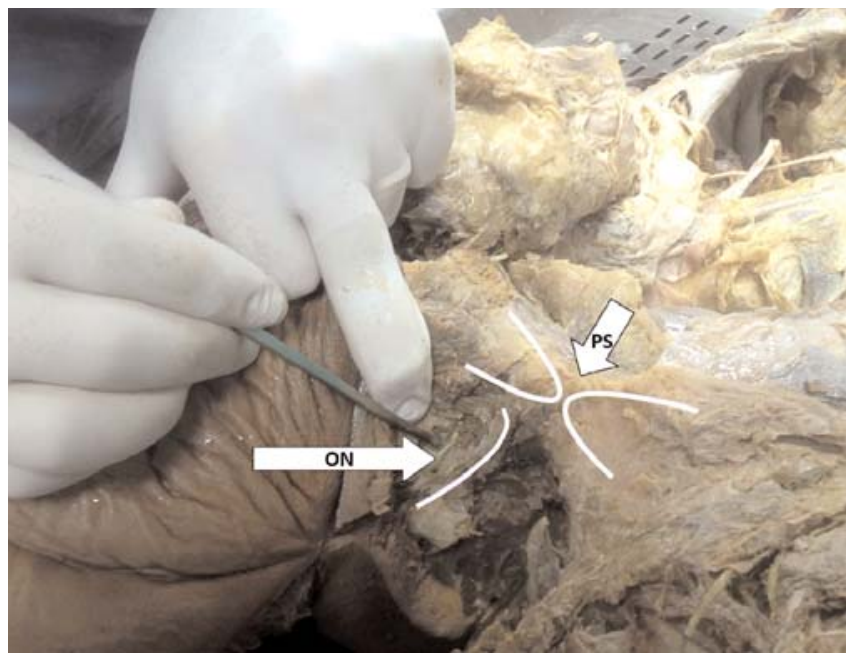

Figure 1. Obturator nerve just after exiting from obturator canal to thigh. ON: obturator nerve; PS: pubic symphisis.

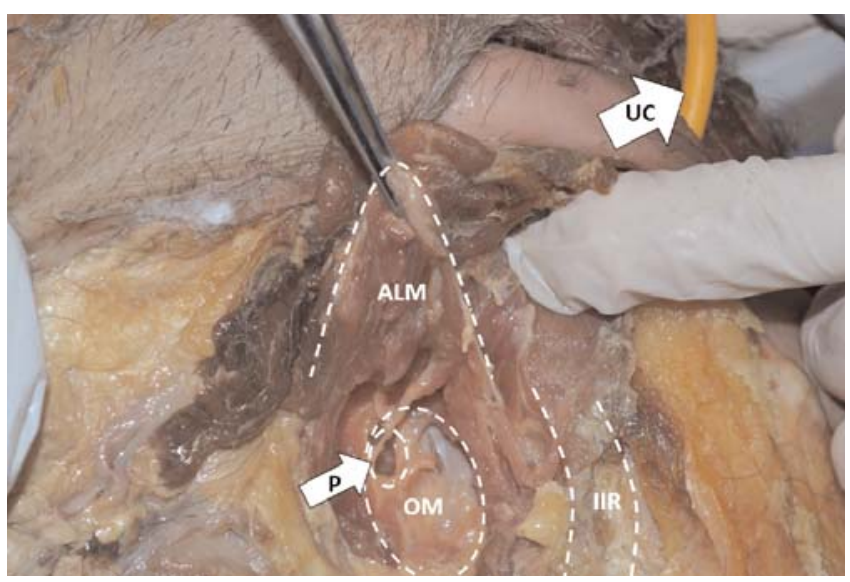

Figure 2. Needle puncture site for outside- inside technique. ALM: adductor longus muscle; IIR: inferior ischiopubic ramus; OM: obturator membrane; P: punctured side of obturator membrane; UC: urethral catheter.

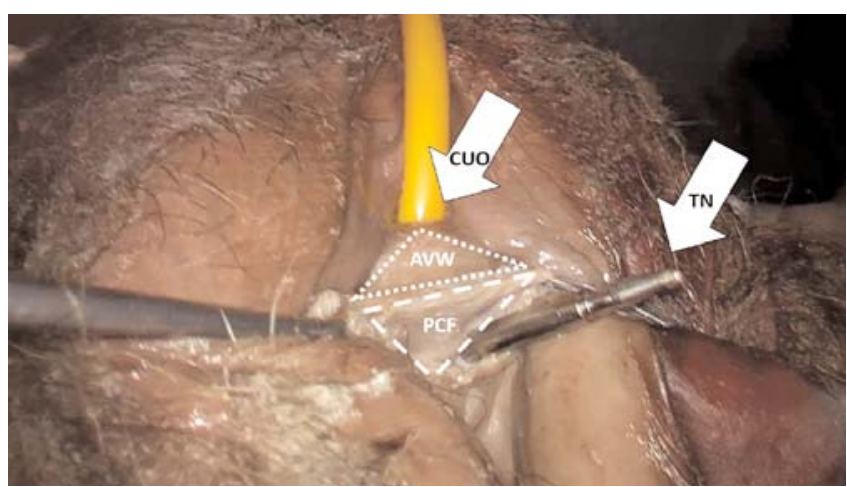

Figure 3. Inside pucture point of TOT needle on pubocervical fascia. AVW: anterior vaginal wall; CUO: catheterized urethral orifice; PSF: pubocervical fascia; TN: TOT needle. 
should be pulled up equally from both sides. The pressure between the mesh and the urethra has to be controlled with a surgical clamp. At the end of the sling placement, the avoidance of any contact between the mesh and the adductor longus tendon has an importance in precaution of postoperative leg pain.

Cystoscopy should routinely be performed. In case of any bladder injury the needle has to be replaced. If there is any suspicion of urethral injury the sling should not be placed. ${ }^{[7]}$ Thigh incisions could be closed with subcuticular sutures. At the end of the surgical procedure vaginal packing should be made with antibiotic or oestrogen creams. Postoperatively the urethral catheter could be removed in the first day

\section{Anatomic Complications}

When applying the TOT operation, the proximity of the obturator canal to the TOT needle, the medially passing artery, vein, nerve and their branches, also their variable location in the obturator canal should be considered. The wrong angulation during insertion may result in damage to the surrounding anatomical structures.

The major vascular and neurologic structures are mainly located in superolateral part of the obturator foramen. The course of the obturator vessels-nerve bundle shows variations. Location of the obturator vessels, especially the obturator vein varies. The obturator vein may extend from ischial spine to obturator canal. ${ }^{[10]}$ During the TOT procedure, traversing branches of obturator vessels are at high risk of injury. In a study, bilateral obturator foramina were dissected in nine female cadavers. Approximately \%20 of the obturator vessels traversed medially through the obturator membrane looking towards to the needle placement side. ${ }^{[1]}$ Vascular complications may lead to retropubic or obturator hematoma. ${ }^{[12]}$ Obturator nerve injuries during TOT procedure have been reported in the literature..$^{[13,14]}$ When obturator nerve is injured, leg adduction will be restricted and the patient may not be able to walk independently because of the loss of motor strength. Low urinary tract injury is a very rare complication of TOT ${ }^{[15,16]}$ In the early stage, haematuria may be the only sign of the injury. These injuries can be recognized early with cystoscopy during the procedure. Completely emptying the bladder before the procedure can reduce the possibility of perforation during needle passage.

\section{Conclusion}

Knowledge of anatomical structures is crucial for any surgical approach. There are remarkable variations in the bony architecture of the female pelvis and this variability may have an important effect on sling operations. ${ }^{[17]}$ Understanding surgical anatomy of the obturator foramen, pelvic floor and perineum is necessary to make a successful implantation of transobturator tape (TOT) and minimize morbidity. Cadaveric dissections are helpful to demonstrate the anatomic landmarks.

\section{References}

1. Reynolds WS, Dmochowski RR, Penson DF. Epidemiology of stress urinary incontinence in women. Curr Urol Rep 2011;12: $370-6$.

2. Barry C, Lim YN, Muller R, Hitchins S, Corstiaans A, Foote A, Greenland H, Frazer M, Rane A. A multi-centre, randomised clinical control trial comparing the retropubic (RP) approach versus the transobturator approach (TO) for tension-free, suburethral sling treatment of urodynamic stress incontinence: the TORP study. Int Urogynecol J Pelvic Floor Dysfunct 2008;19: $171-8$.

3. Standring S. Pelvic girdle, gluteal region and thigh. In: Standring $\mathrm{S}$, editor. Gray's anatomy. The anatomical basis of clinical practice. 40th ed. Edinburgh: Elsevier Churchill Livingstone; 2008. p. 1349-85

4. Hanissian P, Whiteside J. The transobturator approach to midurethral sling. In: Graham SD, Keane TE, editors. Glenn's urologic surgery. 7th ed. Philadelphia: Lippincott Williams \& Wilkins; 2010. p. 282-7.

5. Dmochowski RR, Padmanabhan P, Scarpero HM. Slings: autologous, biologic, synthetic, and midurethral. In: Wein AJ, Kavoussi LR, Novick AC, Partin AW, Peters CA, editors. Campbell-Walsh urology. 10th ed. Philadelphia: Saunders Elsevier; 2012. p. 2115-67.

6. Cheung RY, Chan SS, Yiu KW, Chung TK. Inside-out versus outside-in transobturator tension-free vaginal tape: a 5-year prospective comparative study. Int J Urol 2014;21:74-80.

7. Dmochowski RR, Wolter CE. Transobturator midurethral sling. In: Smith JA, Howards SS, Preminger GM, editors. Hinman's atlas of urologic surgery. ed. Philadelphia: Elsevier Saunders; 2012. p. $563-66$.

8. Hinoul P, Vanormelingen L, Roovers JP, de Jonge E, Smajda S. Anatomical variability in the trajectory of the inside-out transobturator vaginal tape technique (TVT-O). Int Urogynecol J Pelvic Floor Dysfunct 2007;18:1201-6.

9. Hinoul P, Bonnet P, Krofta L, Waltregny D, de Leval J. An anatomic comparisonof the original versus a modified inside-out transobturator procedure. Int Urogynecol J 2011;22:997-1004.

10. Ersoy M, Sagsoz N, Bozkurt MC, Apaydin N, Elhan A, Tekdemir I. Important anatomical structures used in paravaginal defect repair: cadaveric study. Eur J Obstet Gynecol Reprod Biol 2004; 112:206-13.

11. Ottem D, Stothers L. Transobturator tape: variation in the vascular anatomy of the obturator foramen. Can J Urol 2007;14:367883.

12. Navi A, Turner EJ, Aland RC. The course of the obturator artery following passage through the obturator foramen into the thigh. BMJ Case Rep 2012;pii: bcr0220125898.

13. Paulson JD, Baker J. De novo pudendal neuropathy after TOT-O surgery for stress urinary incontinence. JSLS 2011;15:326-30. 
14. Aydogmus S, Kelekci S, Aydogmus H, Ekmekci E, Secil Y, Ture S. Obturator nerve injury: an infrequent complication of TOT procedure. Case Rep Obstet Gynecol 2014;2014:290382.

15. Abdel-Fattah M, Ramsay I, Pringle S. Lower urinary tract injuries after transobturator tape insertion by different routes: a large retrospective study. BJOG 2006;113:1377-81.

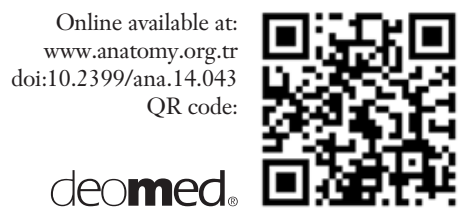

16. Smith PP, Appell RA. Transobturator tape, bladder perforation, and paravaginal defect: a case report. Int Urogynecol J Pelvic Floor Dysfunct 2007;18:99-101.

17. Ridgeway BM, Arias BE, Barber MD. Variation of the obturator foramen and pubic arch of the female bony pelvis. Am J Obstet Gynecol 2008;198:546.e1-4.

Correspondence to: Mustafa F. Sargon, MD, PhD

Department of Anatomy, Faculty of Medicine,

Hacettepe University, Ankara, Turkey

Phone: +90 3123052111 Fax: +90 3123107169

e-mail: mfsargon@hacettepe.edu.tr

Conflict of interest statement: No conflicts declared.

This is an open access article distributed under the terms of the Creative Commons Attribution-NonCommercial-NoDerivs 3.0 Unported (CC BY-NCND3.0) Licence (http://creativecommons.org/licenses/by-nc-nd/3.0/) which permits unrestricted noncommercial use, distribution, and reproduction in any medium, provided the original work is properly cited. Please cite this article as: Huri E, Ezer M, Aydoğan B, Tatar I, Sargon MF. Anatomic transobturator tape (TOT) technique: clinical anatomic landmarks of obturator foramen on female cadavers. Anatomy 2015;9(1):38-41. 